EASTERN REVIEW 2018, T. 7

\title{
Magdalena Tomala
}

\section{Procesy modernizacji w państwach regionu Morza Baltyckiego}

W grudniu 1991 r. podczas szczytu państw europejskich w Maastricht podpisano Traktat o Unii Europejskiej, w którym określono zasady, jakie powinny spełniać państwa do pełnego uczestnictwa w unii gospodarczej i walutowej ${ }^{1}$. Były to warunki konieczne do konwergencji słabo rozwiniętych państw w stosunku do wysoko rozwiniętych państw Europy Zachodniej. Ustalone w Maastricht kryteria dotyczyły m.in. państw Europy Środkowo-Wschodniej, takich jak: Polska, Litwa, Łotwa Estonia, które z państwami nordyckimi oraz Niemcami tworzyły region Morza Bałtyckiego. Należy pamiętać, że trzy z nich: Szwecja, Dania i Finlandia należą do Unii Europejskiej, a Islandia oraz Norwegia stowarzyszone są z nią w ramach europejskiego obszaru gospodarczego ${ }^{2}$.

Celem niniejszego opracowania jest zbadanie procesu konwergencji, jaki nastąpił w okresie od 1992 do 2014 r. (22 lat) w regionie Morza Bałtyckiego. Można zadać pytanie, czy integracja z UE przyczyniła się do polaryzacji, czy też do konwergencji tego obszaru? ${ }^{3} \mathrm{~W}$ pracy wykorzystano założenia teorii neoliberalnej, która podkreśla wielość podmiotów stosunków międzynarodowych, występujących obok państwa oraz sieć powiązań między polityką, ekonomią czy prawem. Podejście to pozwala na płynne przechodzenie z jednego sektora do drugiego, co implikuje powstawanie współzależności między nimi. Można ją zdefiniować (interdependence) za O. Youngiem jako zakres, w jakim wydarzenia w jednej części systemu światowego wpływają na wydarzenia w innych częściach tego systemu.

${ }^{1}$ Traktat o Unii Europejskiej, https://polskawue.gov.pl/files/polska_w_ue/prawo/traktaty/ Traktat_z_Maastricht.pdf (dostęp 29.12.2015).

$2 \bar{Z} \mathrm{ob}$. szerzej: J. Grzela, Teoria i praktyka wspótpracy regionalnej na przykładzie Regionu Morza Battyckiego, Kielce 2010.

3 Zob. T. Geodecki, Procesy konwergencji i polaryzacji w regionach Unii Europejskiej, „Zeszyty Naukowe Akademii Ekonomicznej w Krakowie" 2006, nr 714, s. 75-77.

${ }^{4}$ O.R. Young, Interdependence in the World Politics, „International Journal” 1969, no. 24, s. $726-750$. 
Podkreślić należy, że wskazana współzależność jest wynikiem intensywnej wymiany ekonomicznej, która wpływa na stosunki polityczne ${ }^{5}$. W artykule wykorzystano metodę porównawczą, dzięki której starano się ukazać zależności między procesem dostosowawczym do kryteriów z Maastricht a rozwojem gospodarczym państw, mierzonym jako produkt krajowy brutto na osobę (według parytetu siły nabywczej). Artykuł składa się z trzech części. W pierwszej omówiono główne założenia procesu modernizacji, jakie stawiały sobie państwa w tej części Europy. Następnie ukazano poziom zbieżności omawianych państw z kryteriami konwergencji. W ostatniej części omówiono zależność między poziomem migracji a napływem inwestycji bezpośrednich, które to wpływają na wyrównanie poziomu rozwoju gospodarczego w regionie bałtyckim.

\section{Region Morza Baltyckiego - aspiracje a rzeczywistość}

Zapoczątkowanie procesów modernizacji w regionie Morza Bałtyckiego wynikało bezpośrednio z przemian systemowych przełomu lat 80 . i 90 . XX w. ${ }^{6}$ Wraz z upadkiem muru berlińskiego pojawiły się naturalne warunki dla bliższej kooperacji w tym obszarze. Granice państwowe oraz podział na socjalistyczny Wschód i kapitalistyczny Zachód przestał być podstawową przeszkodą w procesach integracyjnych regionu bałtyckiego. Zaczęła wypełniać się pusta przestrzeń w relacjach między państwami UE, północnej i środowowschodniej Europy?.

Pierwszy krok na drodze do integracji ze strukturami EWG wykonała Polska, która zadeklarowała zmianę systemu ekonomiczno-politycznego ${ }^{8}$. Podjęła decyzję o wprowadzeniu gospodarki rynkowej i instytucji demokratycznych. Transformacja systemowa została zapoczątkowana już we wrześniu 1989 r. Wówczas na czele pierwszego niekomunistycznego rządu stanął T. Mazowiecki, a za zmiany w systemie funkcjonowania gospodarki wziął odpowiedzialność L. Balcerowicz. Jego plan miał na celu stworzenie warunków przywrócenia zachwianej kryzysem lat $80 . \mathrm{XX}$ w. równowagi rynkowej w ramach podstawowych segmentów rynku: dóbr i usług, kapitału i pracy9 ${ }^{9}$ Również państwa bałtyckie rozpoczęły proces bu-

${ }^{5}$ Zob. J. Czaputowicz, Teorie stosunków międzynarodowych. Krytyka i systematyzacja, Warszawa 2007, s. 217.

${ }^{6}$ Rządowe Centrum Studiów Strategicznych, Transformacja społeczno-gospodarcza w Polsce, Warszawa 2002, s. 26-28.

7 Zob. J. Wojnicki, Trudna droga do demokracji. Europa Środkowo-Wschodnia po 1989 roku, Warszawa 2002.

${ }^{8}$ Zob. B. Siuta-Tokarska, Zarys wybranych problemów społeczno-gospodarczych Polski $w$ okresie transformacji systemowej a polityka gospodarcza państwa, Uniwersytet Ekonomiczny w Krakowie, s. 44 i n., http://www.ur.edu.pl/pliki/Zeszyt19/03.pdf (dostęp 2.01.2016).

${ }^{9}$ A. Prusek, Prywatyzacja polskiej gospodarki. Cele, programy i ocena jej rezultatów, Kraków 2005. 
dowania niepodległej i demokratycznej państwowości. Litwa 11 marca 1990 r., Estonia - 30 marca 1990 r., a Łotwa 4 maja 1990 r. proklamowały niepodległość. Mimo odzyskania suwerenności nie posiadały one podstawowych atrybutów niepodległości, jak własna armia, waluta, skutecznie chronione granice państwowe czy strategiczne dla bezpieczeństwa systemy infrastruktury, a odzyskana suwerenność komplikowana była dodatkowo obecnością Armii Czerwonej na ich terytorium.

Procesy przemian systemowych od początku wspierały państwa Europy Zachodniej oraz Północnej. Nadrzędnym priorytetem dla nowo utworzonych państw było podjęcie i rozwój współpracy bałtyckiej, która zapewniłaby im nieodwracalność odzyskania suwerenności oraz ustabilizowanie sytuacji politycznej i rozwój gospodarczy. Warto podkreślić wsparcie dla integracji z UE takich polityków, jak: J. Majora w Wilnie 1 maja 1994 r., B. Clintona w Rydze 6 lipca 1994 r. oraz w Warszawie 26 czerwca $1996 \mathrm{r}$.

Należy zauważyć, że aspiracje Litwy, Łotwy, Estonii i Polski wspierały przede wszystkim państwa nordyckie. Ich przedstawiciele zwracali uwagę na potrzebę integracji regionu Morza Bałtyckiego oraz jego zrównoważony rozwój. Już w Wilnie w 1991 r., podczas szczytu państw w ramach Grupy Nordic-Baltic 8, podkreślano, że współpraca bałtycka przynosi same korzyści i gwarantuje nowym członkom finansową oraz technologiczną pomoc. Obok integracji z UE istniała w regionie bałtyckim zgoda na pogłębianie procesów integracji i modernizacji tego obszaru. Zarówno w okresie przedakcesyjnym, jak i po 2004 r. powstało wiele inicjatyw na poziomie rządowym, regionalnym oraz pozarządowym, które za cel stawiały sobie rozwój regionalny. Najważniejsze to powstanie Rady Państw Morza Bałtyckiego $(1992)^{10}$, utworzenie w ramach UE wymiaru północnego $(1997)^{11}$ czy przygotowanie Strategii Rozwoju Regionu Morza Bałtyckiego ${ }^{12}$.

Te, jak i wiele innych inicjatyw współpracy regionalnej tworzyły swego rodzaj sieć powiązań instytucjonalnych, w ramach których starano się diagnozować najważniejsze potrzeby regionu oraz wyznaczać strategiczne cele rozwojowe ${ }^{13}$. Istotą procesów zachodzących $\mathrm{w}$ regionie bałtyckim była ciągłość podejmowanej współpracy w okresie ponad 20 lat, co w rezultacie powinno przyczynić się do osiągnięcia zakładanych sobie celów (szczególnie w państwach położonych na południowym brzegu Bałtyku).

${ }^{10}$ I. Śmigerska-Belczak, Wspótpraca w regionie Morza Battyckiego - Rada Państw Morza Battyckiego, http://kolegia.sgh.waw.pl/pl/KES/kwartalnik/archiwum/Documents/ISmigerska-Belczak9.pdf (dostęp 11.01.2016).

${ }_{11}$ M. Tomala, R.M. Czarny, Wymiar pótnocny Unii Europejskiej. Studium rozwoju, Kielce 2009.

${ }_{12}$ Zob. Unijna Strategia dla regionu Morza Bałtyckiego - ku zrównoważonej, dostatniej przyszłości, „Panorama Inforegio” 2009, nr 30, http://ec.europa.eu/regional_policy/sources/docgener/ panorama/pdf/mag30/mag30_pl.pdf (dostęp 29.12.2015).

${ }^{13}$ Ch. Ketels, State of the Region Report, Baltic Development Forum, Copenhagen 2011, s. 99. 
Kluczowe znaczenie z punktu widzenia polskich, łotewskich, litewskich oraz estońskich starań o członkostwo miało sformułowanie politycznych i gospodarczych kryteriów, od których spełnienia uzależnione było przyjęcie do UE czterech kandydujących państw. Wśród najważniejszych należy wymienić: stabilność instytucji gwarantujących zasady demokracji i praworządności, przestrzeganie praw człowieka i podstawowych wolności, funkcjonowanie gospodarki wolnorynkowej, zdolność kraju do sprostania konkurencji oraz siłom rynkowym wewnątrz $U^{14}$. Analizując proces starań państw, położonych na południowym brzegu Bałtyku, należy zauważyć, iż spełnienie kryteriów z Kopenhagi pozwoliło tym państwom na podjęcie kolejnych kroków na drodze integracji europejskiej, zakończone 1 maja 2004 r. akcesją do UE. Poza tym uczestnictwo w strukturach unijnych w następnych latach pozwoliło na dalszy proces modernizacji poszczególnych państw, jak i całego regionu Morza Bałtyckiego.

\section{Państwa regionu Morza Baltyckiego wobec kryteriów konwergencji UE}

Konwergencja oznaczała proces wyrównywania zmiennych ekonomicznych między poszczególnymi państwami bądź regionami ${ }^{15}$. Konwergencję realną można zdefiniować jako wyrównywanie się poziomów rozwoju gospodarczego, najszybciej obrazowanego jako PKB per capita, mierzonego parytetem siły nabywczej. Jest ona możliwa poprzez szybszy rozwój państw słabo rozwiniętych. Istotne założenia tego procesu w ramach struktur UE zostały ustalone w 1992 r. w Maastricht. W ramach integracji europejskiej państwa aspirujące do członkostwa zobowiązane zostały do wypełnienia kryteriów zbieżności. Można je podzielić na dwie grupy: kryteria monetarne (inflacja, długookresowe stopy procentowe oraz kursy walutowe) oraz fiskalne (deficyt budżetowy, dług publiczny). Ich wypełnienie miało stanowić gwarancję rozwoju gospodarczego oraz wejścia do ścisłej grupy państw, mających wspólną walutę euro ${ }^{16}$.

Należy zauważyć, że w regionie Morza Bałtyckiego nie doszło do pełnej konwergencji państw (zob. tabela 1).

${ }^{14}$ Koncepcja ustrojowa i instytucjonalna II filara Unii Europejskiej, [w:] Unia Europejska, t. II, Gospodarka - Polityka - Wspótpraca, red. W.M. Góralski, Warszawa 2007, s. 125.

${ }^{15}$ W wyniku wejścia w życie Traktatu Lizbońskiego znalazły się one głównie w art. 140 Traktatu o funkcjonowaniu Unii Europejskiej (dawny Traktat ustanawiający Europejską Wspólnotę Gospodarczą $\mathrm{nr} 13$ w sprawie kryteriów konwergencji).

${ }^{16} \mathrm{~W}$ rozważaniach teoretycznych na temat unii walutowej najczęściej akcentowane są pozytywne skutki jej utworzenia dla wzrostu gospodarczego w krajach członkowskich - zob. H.G. Grubel, International Economics, Yale 1977; P. Robson, The Economics of International Integration, London 1984; P. Kenen, The theory of optimum currency areas: An eclectic view, [w:] Monetary Problems of the International Economy, eds R. Mundell, A. Svoboda, Chicago 1969. 
Tabela 1. Struktury integracji w ramach regionu Morza Bałtyckiego

\begin{tabular}{|c|c|c|}
\hline Region Morza Bałtyckiego & Unia Europejska & Warunki w strefie euro \\
\hline Dania & 1.01 .1973 & ERM2/O \\
\hline Estonia & 1.05 .2004 & ERM2/D \\
\hline Finlandia & 1.01 .1995 & EA \\
\hline Islandia & $\mathrm{x}$ & $\mathrm{x}$ \\
\hline Litwa & 1.05 .2004 & ERM2/D \\
\hline Łotwa & 1.05 .2004 & ERM2/D \\
\hline Niemcy & 3.10 .1990 & EA \\
\hline Norwegia & $\mathrm{x}$ & $\mathrm{x}$ \\
\hline Polska & 1.05 .2004 & $\mathrm{D}$ \\
\hline Rosja & $\mathrm{x}$ & $\mathrm{x}$ \\
\hline Szwecja & 1.01 .1995 & $\mathrm{D}$ \\
\hline
\end{tabular}

Źródło: opracowanie własne na podstawie: M. Albinowski, $P M$ - Monitor konwergencji nominalnej, Ministerstwo Finansów, http://www.mf.gov.pl/c/document_library/get_file?uuid=b026db7d -51c3-4321-81d7bbe914846a08\&groupId=764034 (dostęp 29.12.2015).

Jak wynika z tabeli 1, państwa regionu Morza Bałtyckiego nie przyjęly jednej ścieżki integracyjnej. Dotyczy to zarówno członkostwa w UE, jak i unii gospodarczej i walutowej. Członkami strefy euro (EA) zostały Finlandia oraz Niemcy, do mechanizmu wzajemnej stabilizacji kursów walutowych ERM2 (Exchange Rate Mechanizm) przystąpiły Estonia, Litwa, Łotwa, przy czym Dania z klauzulą opt-out (O). Daje ona prawo wyboru, czy pozostanie przy własnej walucie, czy też zdecyduje się w przyszłości na przyjęcie euro. Pozostałe państwa, w tym właśnie Polska i Szwecja, określane są mianem państw z derogacją (D). Oznacza to, iż w przeciwieństwie do Danii są one zobowiązane po wypełnieniu niezbędnych warunków na przyjęcie euro.

Najsłabiej z regionem Morza Bałtyckiego jest powiązana Rosja, która poza działalnością w ramach Rady Państw Morza Bałtyckiego nie uczestniczy w procesach integracji europejskiej oraz pozostaje poza współpracą na rzecz bezpieczeństwa (NATO). Norwegia oraz Islandia pozostały poza strukturami Unii Europejskiej, choć przystąpiły do rynku wewnętrznego w ramach europejskiego obszaru gospodarczego ${ }^{17}$. Spośród państw regionu Morza Bałtyckiego do strefy euro w 2004 r. przystąpiły tylko dwa: Finlandia, Niemcy. Choć w Szwecji obowiązują przepisy Traktatu z Maastricht w sprawie wspólnej waluty, jednak 4 grudnia 1997 r. parla-

17 Agreement on the European Economic Area, http://www.efta.int/sites/default/files/d ocuments/ legal-texts/eea/the-eea-agreement/Main $\% 20 \mathrm{Text} \% 20 \mathrm{of} \% 20$ the $\% 20$ Agreement/EEAagreement.pdf (dostęp 14.10.2014). 
ment przyjął deklarację w sprawie nieuczestniczenia jej w obszarze euro od 1 stycznia 1999 r. W związku z tym nie weszła ona do ERM II, a w referendum konstytucyjnym z 14 września 2003 r. większość społeczeństwa zagłosowała przeciwko wprowadzeniu euro. Z kolei Dania na skutek uzyskania w 1993 r. klauzuli opt-out nie przystąpiła do Traktatu z Maastricht. Przyczyną takiej decyzji był również negatywny wynik referendum z 28 września 2000 r. Wymagane kryteria zbieżności udało się wypełnić jako pierwszej Estonii, dzięki czemu 1 stycznia 2011 r. przystąpiła do strefy euro. Następnie do tego grona dołączyła 1 stycznia 2014 r. Łotwa, a rok później Litwa. Zgodnie z raportem Monitora Konwergencji Nominalnej, opublikowanego przez MinisterstwoFinansów, Polska pozostała poza strefą euro, wypełniając cztery z pięciu kryteriów konwergencji nominalnej ${ }^{18}$.

Pierwszym ze wskaźników, który należy wziąć pod uwagę, jest stopa inflacji. Według kryteriów z Maastricht nie powinna być wyższa niż o 1,5 p.proc. od średniej stopy inflacji w trzech państwach UE, gdzie inflacja jest najniższa. Obecnie Polska, podobnie jak inne państwa regionu Morza Bałtyckiego (poza Szwecją) znajduje się wśród krajów, które wypełniły kryterium inflacji (zob. rysunek 1).

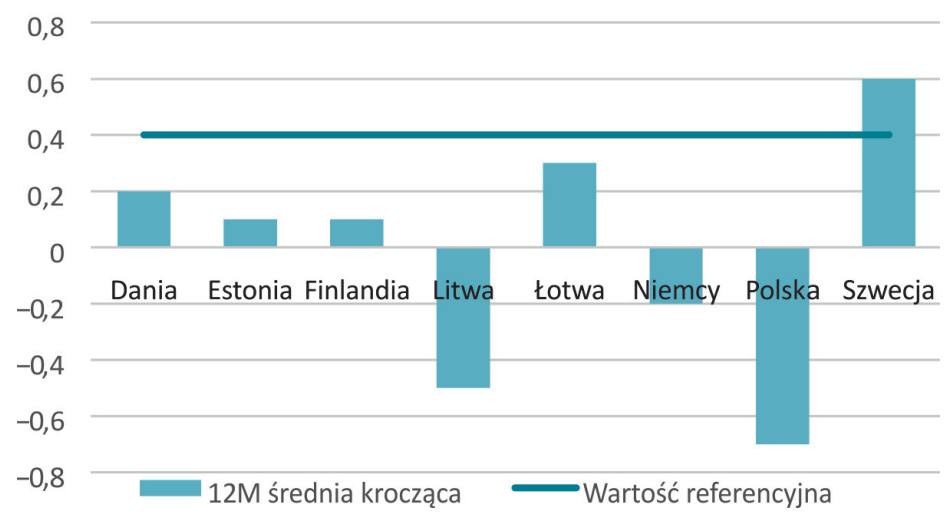

Rysunek 1. Kryterium stabilności cen w państwach regionu Morza Bałtyckiego (za wrzesień 2015 r.)

Źródło: opracowanie własne na podstawie: M. Albinowski, PM-Monitor konwergencji nominalnej, Ministerstwo Finansów, http://www.mf.gov.pl/c/document_library/get_ file?uuid=b026db7d-51c3-4321-81d7bbe914846a08\&groupId=764034 (dostęp 29.12.2015).

Jedynym państwem z regionu bałtyckiego, któremu nie udało się wypełnić kryterium inflacji, jest Szwecja. Z kolei średnie 12-miesięczne tempo wzrostu indeksu HICP w Polsce wyniosło $-0,7 \%$ (historycznie najniższy poziom) i było niższe o 1,1 p.proc. od wartości referencyjnej. Wartość referencyjna $(0,4)$ została obliczona na podstawie danych z 3 państw UE o najbardziej stabilnych cenach, wśród których znalazły się Cypr, Polska i Hiszpania. Z grupy referencyjnej zostały wykluczone

18 S.I. Bukowski, The Maastricht Convergence Criteria and Economic Growth in the EMU, http://www.ec.unipg.it/DEFS/uploads/quad24.pdf (dostęp 30.12.2015). 
Grecja oraz Bułgaria, w których średnie 12-miesięczne tempo wzrostu cen było znacząco niższe od średniej w strefie euro (odpowiednio o 1,7 i 1,4 p.proc.).

Kolejnym ważnym kryterium jest poziom długoterminowych stóp procentowych, który nie powinien przekraczać o więcej niż 2 p.proc. średniej stóp procentowych w trzech państwach UE o najniższej inflacji (zob. rysunek 2).

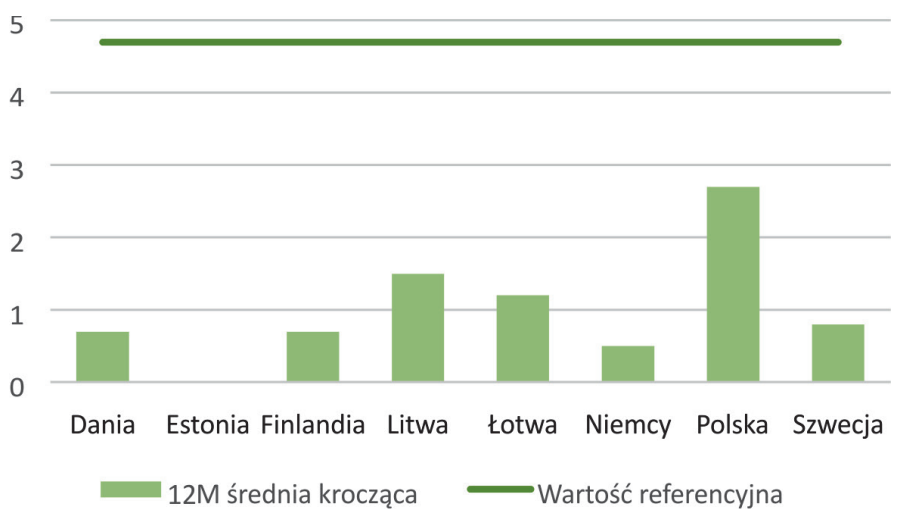

Rysunek 2. Kryterium stóp procentowych w państwach regionu Morza Bałtyckiego (za wrzesień 2015 r.)

Źródło: jak na rysunku 1.

W 2015 r. wszystkie państwa regionu Morza Bałtyckiego należące do UE wypełniały kryterium stóp procentowych. Średnia długoterminowa stopa procentowa za ostatnie 12 miesięcy w Estonii była najniższa ( 0 p.proc.), w Polsce natomiast najwyższa (2,7 p.proc.). Niemniej jednak ukształtowała się o 1,6 p.proc. poniżej wartości referencyjnej, która wyniosła 4,7 p.proc.

Kolejne kryterium ma charakter fiskalny. Określa, że deficyt budżetowy nie powinien być wyższy niż 3\% PKB (zob. rysunek 3).

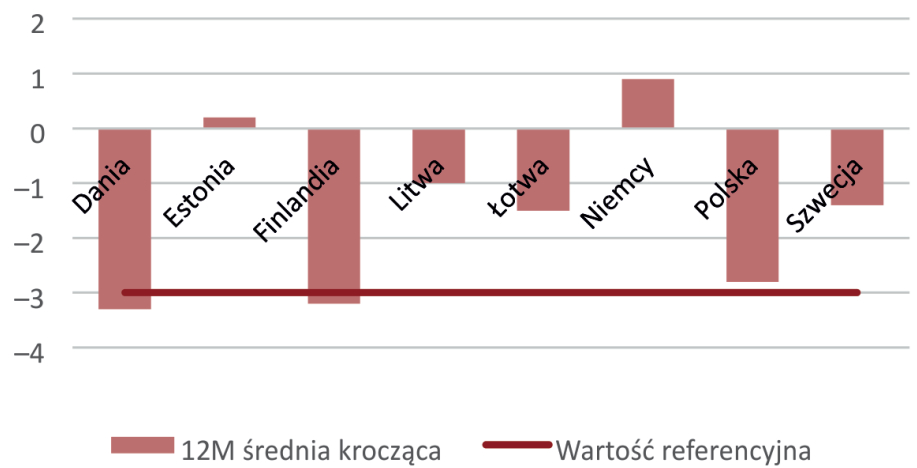

Rysunek 3. Kryterium deficytu budżetowego w państwach regionu Morza Bałtyckiego (za wrzesień 2015 r.)

Źródło: jak na rysunku 1. 
Jedynie w przypadku Finlandii Rada Ecofin rekomendowała wprowadzenie procedury likwidacji nadmiernego deficytu budżetowego. Jednak Dania również przekroczyła o 0,3\% kryterium z Maastricht. W przypadku Polski te zalecenia 15 czerwca 2015 r. zostały wypełnione. Tym samym Polska zredukowała nadmierny deficyt o rok wcześniej niż było to rekomendowane przez Radę. W 2014 r. deficyt sektora instytucji rządowych i samorządowych w Polsce wyniósł 3,2\% PKB, a przekroczenie wartości referencyjnej wynoszącej 3\% PKB wynikało wyłącznie z poniesionego w tym roku kosztu wdrożenia systemowej reformy emerytalnej z 1999 r. (0,4\% PKB). Skorygowana wartość deficytu sektora general government w 2014 r. wyniosła zatem 2,8\%. Pozostałe państwa regionu Morza Bałtyckiego spełniły zalecenia Rady Ecofin.

W przypadku długu publicznego dwa państwa regionu nie wypełniły zaleceń utrzymania go na poziomie nieprzekraczającym 60\% PKB (zob. rysunek 4).

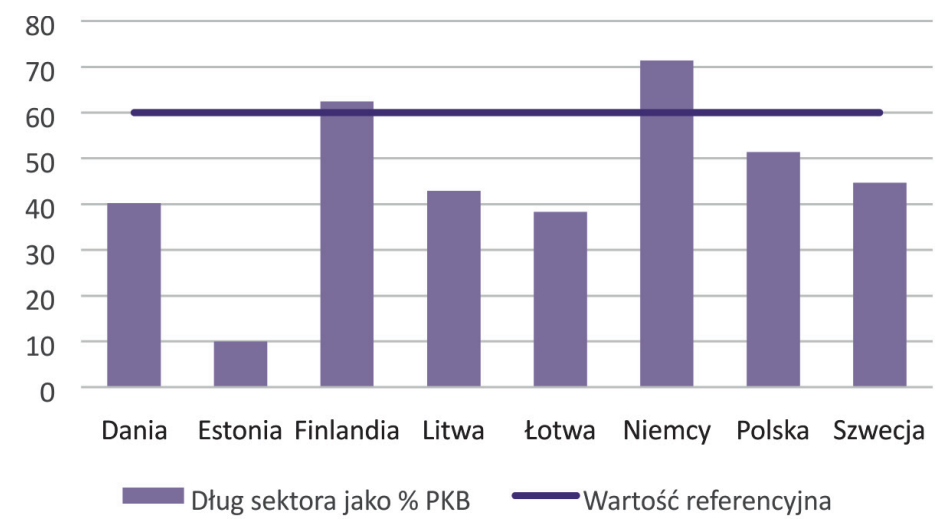

Rysunek 4. Kryterium długu publicznego w państwach regionu Morza Bałtyckiego (za wrzesień $2015 \mathrm{r}$.) Źródło: jak na rysunku 1.

Dług sektora Estonii osiągnął najmniejszą wartość, bo tylko 10\% PKB, znacznie poniżej wartości referencyjnej. Zarówno Finlandia, jak i Dania przekroczyły dopuszczalny limit długu publicznego.

Ostatnim z omawianych kryteriów jest stabilny kurs wymiany waluty w ciągu ostatnich 2 lat. Oznacza on, iż wahania kursów walut nie mogą przekroczyć $\pm 15 \%$ do ustalonej początkowo wartości. Jest to niezbędny warunek dla wprowadzenie waluty do Mechanizmu Kursów Walutowych ERM2. Trzy państwa bałtyckie: Litwa, Łotwa i Estonia w ostatnim okresie spełniły wymagane kryteria, stając się uczestnikami unii walutowej. Jedynie Polska pozostała poza strefą euro. W jej przypadku kryterium kursu walutowego nie jest wypełnione ze względu na fakt, że Polska nie uczestniczy w mechanizmie ERM2. Wchodząc w 2004 r. do Unii Europejskiej, Polska zobowiązała się do przyjęcia wspólnej waluty, jednak bez określania terminów.

Podsumowując powyższe rozważania, należy zauważyć, że zbadane cztery wskaźniki: poziom inflacji, długu publicznego, deficytu budżetowego oraz długo- 
terminowe stopy procentowe w państwach regionu Morza Bałtyckiego potwierdzają wysiłek, który włożyła Litwa, Łotwa, Estonia oraz Polska, aby wypełnić przyjęte założenia o procesie konwergencji z UE. Analiza danych pokazuje, iż pod względem wskazanych przez UE wytycznych nowi członkowie utrzymują reżim monetarny i fiskalny. Państwom nordyckim oraz Niemcom zdarzały się przypadki odstąpienia od wymaganych kryteriów konwergencji niezależnie od tego, czy należały do strefy euro, do mechanizmu ERM2, czy pozostawały poza ramami unii walutowej. Należy również podkreślić, iż Litwa, Łotwa i Estonia osiągnęły lepsze wyniki niż Polska w trzech kategoriach: deficytu budżetowego, długu publicznego, długoterminowych stóp procentowych. Jedynie pod względem stabilności cen Polska okazała się liderem w regionie (jak też w całej UE).

\section{Konwergencja czy polaryzacja regionu Morza Bałtyckiego?}

Przedmiotem zainteresowania Unii Europejskiej jest rozwój gospodarczy, który zwiększa się lub zmniejsza w zależności od występowania procesów konwergencji lub polaryzacji. Według Hansena źródłami konwergencji Unii Europejskiej może być wspólny rynek ${ }^{19}$, który przyczynia się do efektywniejszej alokacji czynników produkcji ${ }^{20}$. W świetle klasycznych teorii handlu międzynarodowego przewiduje się wyrównywanie poziomów rozwoju na skutek usunięcia przeszkód w przepływie czynników produkcji (zob. rysunek 5).

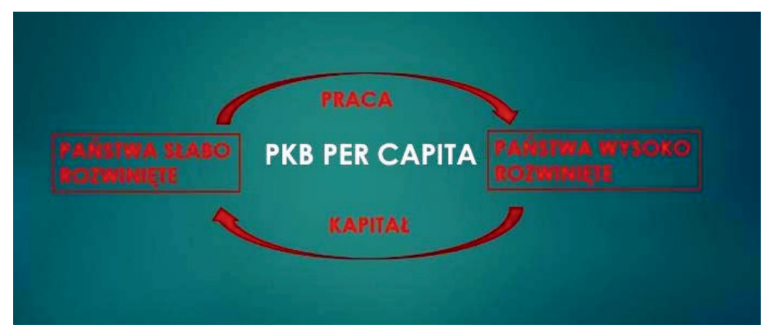

Rysunek 5. Przepływy czynników produkcji

Źródło: opracowanie własne na podstawie: T. Geodecki, Procesy konwergencji i polaryzacji w regionach Unii Europejskiej, „Zeszyty Naukowe Akademii Ekonomicznej w Krakowie” 2006, nr 714.

Jak wynika z rysunku 5, niedostatek kapitału w krajach biedniejszych może zostać zaspokojony jego napływem z krajów bogatszych, zaś siła robocza prze-

19 J. Kundera, Jednolity rynek europejski, Kraków 2003.

${ }^{20}$ D. Hübner, Wpływ członkostwa w Unii Europejskiej na wzrost gospodarczy w Polsce, [w:] Strategia szybkiego wzrostu gospodarczego w Polsce, red. G. Kołodko, Warszawa 2004, s. 99-120. 
mieści się tam, gdzie jest lepiej opłacana. Tym samym, poziomy produktu krajowego w różnych krajach będą dążyły do wyrównania ${ }^{21}$. W jaki sposób kształtował się w regionie Morza Bałtyckiego poziom migracji i inwestycji bezpośrednich? Na rysunku 6 przedstawiono zmiany poziomu migracji w tym regionie w okresie od 1992 do 2012 r.

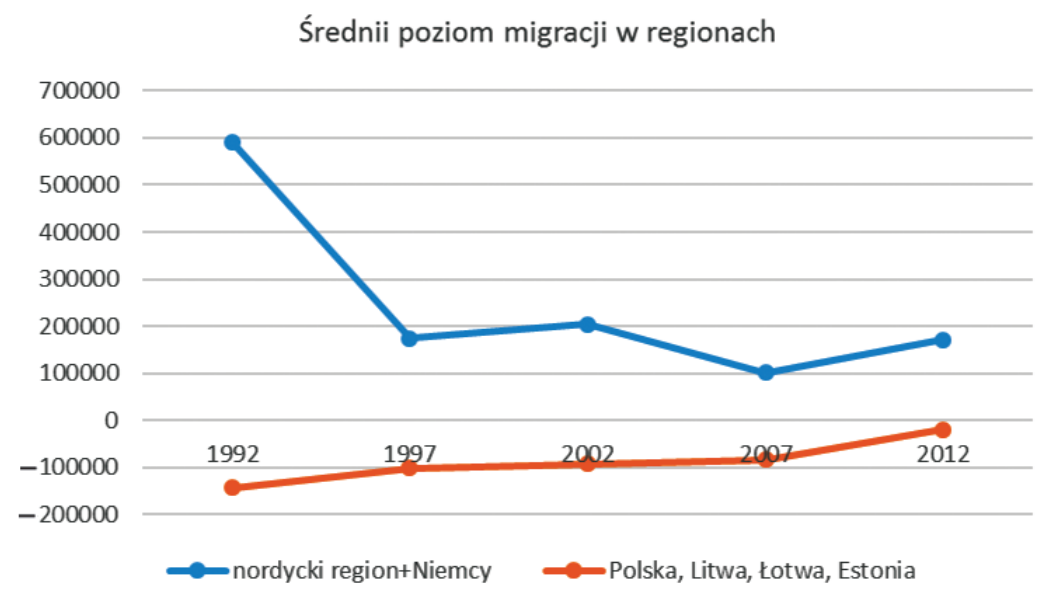

Rysunek 6. Średni poziom migracji w latach 1992-2012

Źródło: opracowanie własne na podstawie: http://data.worldbank.org/indicator/SM.POP.NETM (dostęp 29.12.2015).

Analizując rysunek 6, można zauważyć, iż w państwach biedniejszych (w Polsce, na Litwie, Łotwie i w Estonii) występował ujemny bilans migracji. $\mathrm{Z}$ perspektywy tych państw zauważalna jest poprawa sytuacji w okresie ponad 20 lat, kiedy następowało zmniejszenie emigracji. Odwrotna tendencja występowała w bogatszych krajach północnych: w Niemczech, Szwecji, Danii, Norwegii i Islandii. W przypadku tych państw początek lat 90 . XX w. charakteryzował wysoki poziom imigracji, który w kolejnych latach ulegał zmniejszeniu. Istotne znaczenie dla wyrównywania poziomu rozwoju gospodarczego może mieć to, że nadal poziom migracji jest wyższy niż w przypadku południowych sąsiadów. Poddane analizie dane dotyczące przepływu siły roboczej w regionie Morza Bałtyckiego potwierdzają jednak przyjętą hipotezę o kierunku przepływów siły roboczej z państw biedniejszych do bogatszych. Zmniejszone wartości migracji mogą wynikać z wyrównywania się poziomów rozwoju gospodarczego.

${ }^{21}$ Zob. E. Soszyńska, Różne podejścia do analizy procesów konwergencji gospodarczej, „Zarządzanie Ryzykiem” 2008, nr 28, s. 43-65; M. Boldrin, F. Canova, Inequality and convergence in Europe's regions: Reconsidering European regional policies, „Economic Policy” 2002, vol. 16/32, s. $205-253$. 
Następnym badanym czynnikiem jest poziom napływu inwestycji bezpośrednich $^{22}$, który pozwoli ukazać przepływy kapitałowe w regionie Morza Bałtyckiego. Jego zmiany zostały ukazane na rysunku 7.

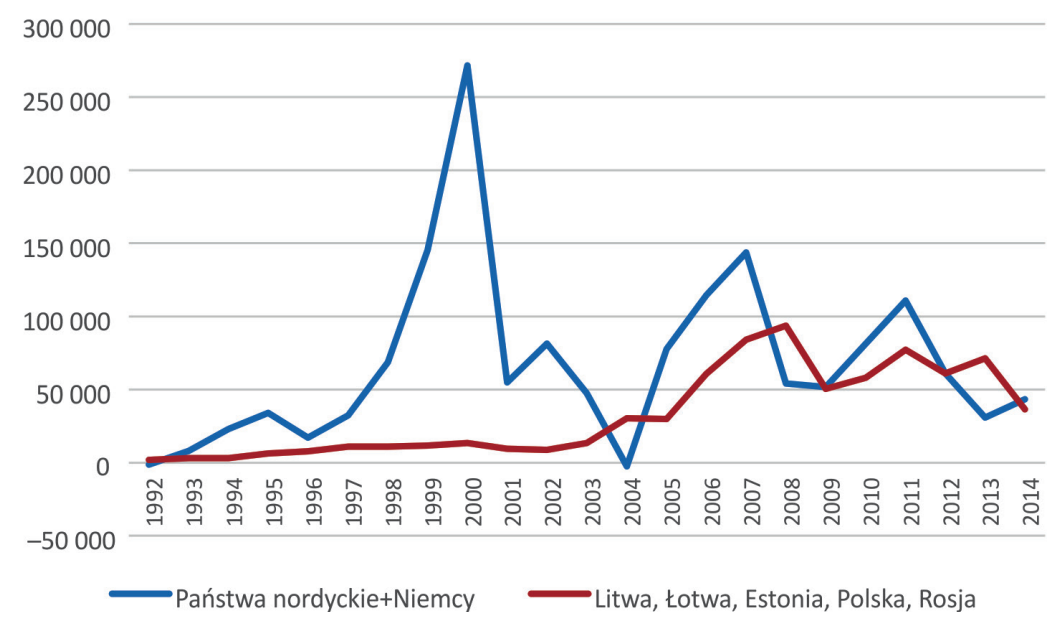

Rysunek 7. Bezpośrednie inwestycje zagraniczne w regionie Morza Bałtyckiego w latach 1992-2014 Źródło: opracowanie własne na podstawie: https://www.conferenceboard.org/data/ economydatabase/index.cfm?id=27762 (dostęp 29.12.2015).

Jak wynika z rysunku 7, w badanym okresie zauważalny jest wzrost napływu inwestycji bezpośrednich do państw biedniejszych. Po akcesji do UE państw południowego Bałtyku widać powolny wzrost napływu inwestycji w regionie. Podobną zależność można zauważyć w przypadku państw nordyckich i Niemiec. Po wejściu do UE Szwecji i Finlandii w 1995 r. i w kolejnych latach również widoczny jest zwiększony napływ inwestycji do tych państw. Również rok 2004 jest przełomowy dla napływu inwestycji do państw nordyckich oraz Niemiec. Do 2007 r. (kiedy mamy do czynienia ze światowym kryzysem finansowym) północni sąsiedzi są równie atrakcyjnym rynkiem inwestycyjnym, a napływ inwestycji rośnie tam nawet szybciej niż w Polsce, na Litwie, Łotwie i w Estonii. Z kolei, w ostatnich latach (od ok. 2007 r.) skala napływu inwestycji staje się porównywalna. Jednak poza kilkoma wyjątkami (rok 2004 i 2013) występuje przewaga BIZ w państwach bogatszych. Z kolei w latach 2009 i 2012 poziom napływu kapitału był na podobnym poziomie $^{23}$. Tym samym nie potwierdza się przyjęta w pracy hipoteza o zwiększonym napływie kapitału do państw biedniejszych kosztem państw bogatszych. Stąd można przypuszczać, iż nie występują wystarczające warunki do tego, aby w regionie Mo-

${ }^{22}$ Zob. Ł. Białek, Przegląd bezpośrednich inwestycji zagranicznych w Europie Środkowej i Wschodniej, „Biuletyn Europy Środkowej i Wschodniej” [b.r.], nr 3.

${ }^{23}$ Globalizacja rynków finansowych - implikacje dla Polski, red. W. Małecki, Warszawa 2007, s. 27-34. 
rza Bałtyckiego nastąpiła konwergencja. Przyczyn takiego stanu można upatrywać we wnioskach typowych dla nowych teorii handlu ${ }^{24}$. Według nich występuje możliwość pogłębienia zróżnicowania dochodów poprzez nierównomierne rozłożenie efektów wzrostu efektywności, które pojawiają się w państwach bogatszych ${ }^{25}$.

\section{Podsumowanie}

Założenia integracji europejskiej pozwalają zakładać, iż realizowana polityka gospodarcza w państwach regionu Morza Bałtyckiego powinna spowodować wyrównanie PKB per capita. Początek lat 90 . XX w. w sposób widoczny ukazał poziom zróżnicowania rozwoju gospodarczego badanych państw (zob. rysunek 8).

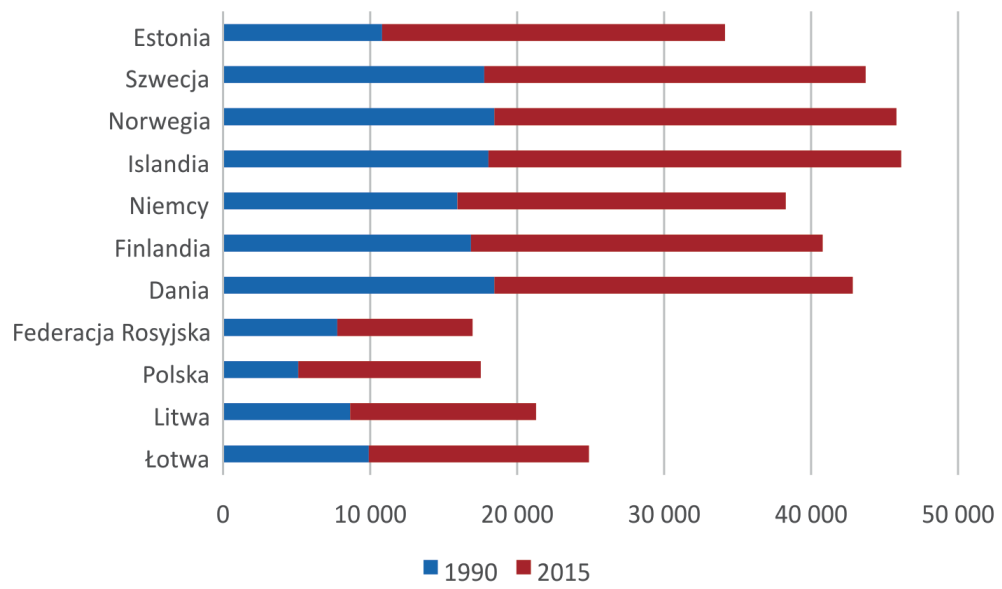

Rysunek 8. Produkt krajowy brutto według parytetu siły nabywczej przy podstawie

Stany Zjednoczone $=100 \%$

Źródło: jak na rysunku 7.

W toku przeprowadzonej analizy dane dotyczące poziomu migracji oraz napływu inwestycji bezpośrednich pozwalają na wyciągnięcie wniosku, iż w regionie Morza Bałtyckiego następuje proces polaryzacji, a nie konwergencji. Wynika to m.in. z mniejszej ilości napływu kapitału, niż miało to miejsce w przypadku pięciu państw nordyckich oraz Niemiec.

${ }^{24}$ M. Grzybowski, Region Morza Battyckiego jako obszar integracji makroregionalnej w Unii Europejskiej,http://webcache.googleusercontent.com/search?q=cache:IOzp6NohDMJ:https://www. msz.gov.pl/ resource/efff7d4c-826e-4208-a4cd-941 f882da938:JCR+\&cd=1\&hl=pl\&ct=clnk\&gl=pl (dostęp 30.12.2015).

${ }^{25}$ D. Hübner, Wpływ członkostwa... 
Z rysunku 7 wynika, że zarówno na początku lat 90 . XX w., jak i obecnie widoczne są w regionie Morza Bałtyckiego dysproporcje rozwojowe. W $1990 \mathrm{r}$. dystans między grupą państw bogatszych w stosunku do biedniejszych wynosił ok. 8900 dol. na osobę (mierzonego według parytetu siły nabywczej), aby w 2015 r. powiększyć się do ok. 9500. Analiza danych dotyczących konwergencji państw regionu Morza Bałtyckiego wskazuje zatem, że w badanym okresie zależność dotycząca szybszego przyrostu PKB w regionach państw biedniejszych i wolniejszego państw bogatszych nie jest wyraźna, aczkolwiek z niekorzystną tendencją pogłębiającą dysproporcje rozwojowe (zob. rysunek 9).

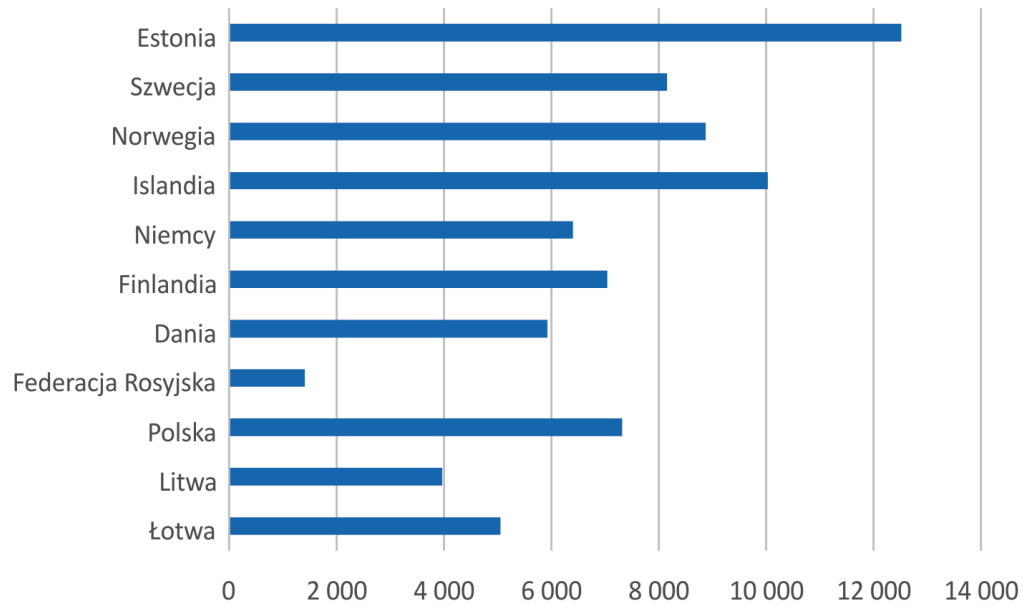

Rysunek 9. Dystans rozwojowy w okresie 1990-2015

Źródło: jak na rysunku 7.

Największy dystans rozwojowy odrobiła Estonia, co przełożyło się na porównywalny PKB per capita liczony według parytetu siły nabywczej do bogatszych państw nordyckich oraz Niemiec. Jest on większy niż w przypadku pozostałych państw południowego Bałtyku. Polsce, Litwie oraz Łotwie nie udało się dokonać takiego postępu gospodarczego. Polska nadrobiła zaległości w stosunku do Danii, Finlandii i Niemiec. Natomiast Litwie i Łotwie nie udało się osiągnąć podobnych rezultatów.

Choć wnioski wskazują na proces polaryzacji regionu Morza Bałtyckiego, warto zwrócić uwagę na dystans rozwojowy, jaki nadrobiły państwa w okresie 25 lat w stosunku do Rosji. Wpływ, jaki miały procesy modernizacyjne na kształtowanie się rozwoju gospodarczego w badanym regionie, prezentuje rysunek 10 . $\mathrm{Z}$ uwagi na brak danych dotyczących byłych republik radzieckich w niniejszym artykule porównano ze sobą PKB per capita w Polsce oraz w Rosji (następnie w Federacji Rosyjskiej) w okresie przed dokonaniem i po dokonaniu procesów modernizacyjnych. 


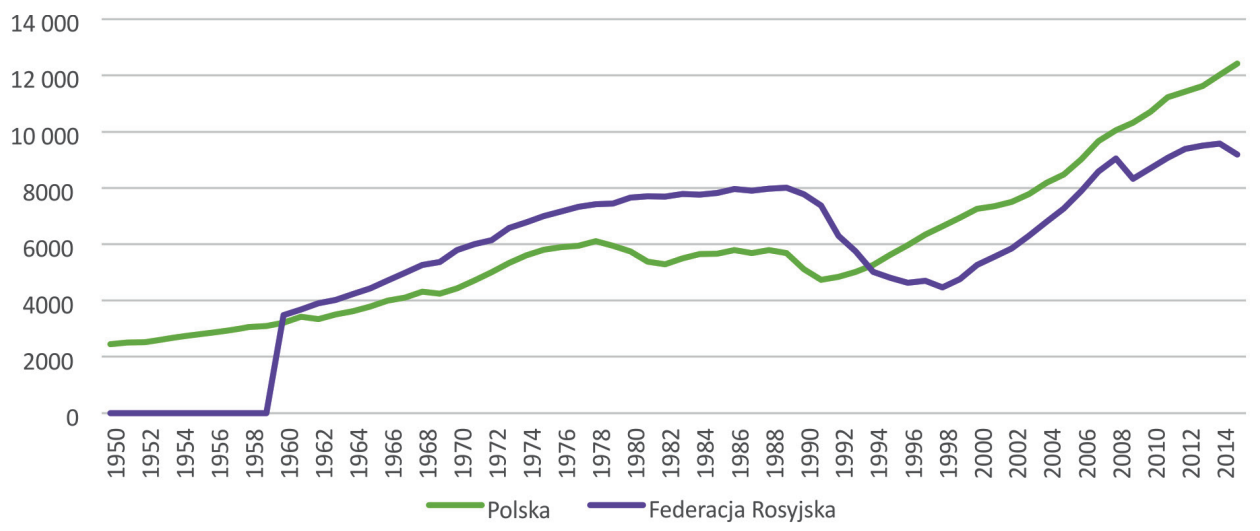

Rysunek 10. Produkt krajowy brutto w Rosji i Polsce przy podstawie Stany Zjednoczone $=100 \%$ Źródło: jak na rysunku 7.

W okresie funkcjonowania Rady Wzajemnej Pomocy Gospodarczej dystans rozwojowy między ZSRR a Polską stale się powiększał. Integracja w ramach bloku wschodniego była korzystniejsza dla lidera regionalnego - czyli ZSRR. Ewolucja, jaka dokonała się na przełomie lat 80. i 90. XX w., zmieniła zależność między państwami. Na rysunku 10 widać, iż rozpad bloku wschodniego przyczynił się do pogorszenia stanu gospodarczego w Rosji. W tym samym czasie Polska zaczęła nadrabiać zaległości względem Rosji, wyprzedzając ją już w 1994 r. Tendencja ta utrzymywała się w kolejnych latach ${ }^{26}$.

Podsumowując powyższe rozważania, nasuwa się wniosek, że zjawisko koncentracji czynników wzrostu w bogatych centrach wzrostu wymusza na państwach, jak i na całej UE stworzenie mechanizmów pobudzania inwestycji w regionach uznawanych za zacofane. Ich zadaniem winno być przyciągnięcie w te obszary kapitału, który w istotny sposób może wpłynąć na rozwój gospodarczy regionu.

\section{Bibliografia}

Agreement on the European Economic Area, http:/www.efta.int/sites/default/files/ documents/legal-texts/eea/the-eea-agreement/Main\%20Text\%20of\%20the $\% 20$ Agreement/ EEAagreement.pdf (dostęp 14.10.2014).

Białek Ł., Przeglad bezpośrednich inwestycji zagranicznych $w$ Europie Środkowej i Wschodniej, „Biuletyn Europy Środkowej i Wschodniej” [b.r.], nr 3.

Boldrin M., Canova F., Inequality and convergence in Europe's regions: reconsidering European regional policies, „Economic Policy” 2002, vol. 16/32.

${ }^{26}$ Zob. M.G. Woźniak, Wzrost gospodarczy w Polsce w latach 90. Czynniki, bariery, perspektywy, Kraków 2002, s. 23-24. 
Czaputowicz J., Teorie stosunków międzynarodowych. Krytyka i systematyzacja, Warszawa 2007.

Geodecki T., Procesy konwergencji i polaryzacji w regionach Unii Europejskiej, „Zeszyty Naukowe Akademii Ekonomicznej w Krakowie" 2006, nr 714.

Globalizacja rynków finansowych - implikacje dla Polski, red. W Małecki, Warszawa 2007. Grubel H.G., International Economics, Yale 1977.

Grzela J., Teoria i praktyka wspótpracy regionalnej na przykładzie Regionu Morza Battyckiego, Kielce 2010.

Grzybowski M., Region Morza Battyckiego jako obszar integracji makroregionalnej w Unii Europejskiej, http://webcache.googleusercontent.com/search?q=cache:IOzp6 NohDMJ:https://www.msz.gov.pl/ resource/efff7d4c-826e-4208-a4cd-941f882da93 $8: \mathrm{JCR}+\& \mathrm{~cd}=1 \& \mathrm{hl}=\mathrm{pl} \& \mathrm{ct}=\mathrm{clnk} \& \mathrm{gl}=\mathrm{pl}($ dostęp 30.12.2015).

Hübner D., Wpływ członkostwa w Unii Europejskiej na wzrost gospodarczy w Polsce, [w:] Strategia szybkiego wzrostu gospodarczego w Polsce, red. G. Kołodko, Warszawa 2004.

Kenen P, The theory of optimum currency areas: An eclectic view, [w:] Monetary Problems of the International Economy, eds R. Mundell, A. Svoboda, Chicago 1969.

Ketels Ch., State of the Region Report, Baltic Development Forum, Copenhagen 2011.

Koncepcja ustrojowa i instytucjonalna II filara Unii Europejskiej, [w:] Unia Europejska, t. II, Gospodarka - Polityka - Wspótpraca, red. W.M. Góralski, Warszawa 2007.

Kundera J., Jednolity rynek europejski, Kraków 2003.

Prusek A., Prywatyzacja polskiej gospodarki. Cele, programy i ocena jej rezultatów, Kraków 2005.

Robson P., The Economics of International Integration, London 1984.

Rządowe Centrum Studiów Strategicznych, Transformacja społeczno-gospodarcza w Polsce, Warszawa 2002.

Siuta-Tokarska B., Zarys wybranych problemów społeczno-gospodarczych Polski w okresie transformacji systemowej a polityka gospodarcza państwa, Uniwersytet Ekonomiczny w Krakowie, http://www.ur.edu.pl/pliki/Zeszyt19/03.pdf (dostęp 2.01.2016).

Soszyńska E., Różne podejścia do analizy procesów konwergencji gospodarczej, „Zarządzanie Ryzykiem" 2008, nr 28.

Śmigerska-Belczak i., Wspótpraca w regionie Morza Bałtyckiego - Rada Państw Morza Battyckiego, http://kolegia.sgh.waw.pl/pl/KES/kwartalnik/archiwum/Documents/ISmi gerska-Belczak9.pdf (dostęp 2.01.2016).

Tomala M., Czarny R.M., Wymiar pótnocny Unii Europejskiej. Studium rozwoju, Kielce 2009.

Traktat o Unii Europejskiej, ttps://polskawue.gov.pl/files/polska_w_ue/prawo/traktaty/ Traktat z Maastricht.pdf (dostęp 29.12.2015).

Unijna Strategia dla regionu Morza Battyckiego - ku zrównoważonej, dostatniej przyszłości, „Panorama Inforegio” 2009, nr 30, http://ec.europa.eu/regional_policy/sources/ docgener/panorama/pdf/mag30/ mag30 pl.pdf (dostęp 2.01.2016).

Wojnicki J., Trudna droga do demokracji. Europa Środkowo-Wschodnia po 1989 roku, Warszawa 2002.

Woźniak M.G., Wzrost gospodarczy w Polsce w latach 90. Czynniki, bariery, perspektywy, Kraków 2002.

Young O.R., Interdependence in the World Politics, „International Journal” 1969, no 24. 


\section{Magdalena Tomala}

\section{Модернизационные процессы в государствах Балтийского региона}

Настоящая статья посвящена явлению конвергенции и предпринимает попытку оценки влияния экономической трансформации 90-ых годов XX века на процесс конвергенции среди государств региона Балтийского моря. Главной целью статьи является определение, приблизились ли друг к другу показатели ВВП экономик стран Балтийского региона на душу населения или все-таки произошло совершенно иначе. В статье подвержены были анализу важнейшие макроэкономические показатели, с целью определения их соотношения между государствами балтийского региона.

Ключевые слова: Балтийский регион, конвергенция, модернизация.

\section{Magdalena Tomala}

\section{Modernization processes in the Baltic Sea Region}

This paper analyses the issue of convergence in the Baltic Sea Region countries and tries to assess the effect of economic transformation during the period of $90 \mathrm{~s}$ in 20th century on the process of convergence. In other words it will consider whether the integration process in the European Union pulled the economies of the organization together or pushed them apart. It will analyse the most important macroeconomic data to establish the relationships between counties in the Baltic Sea Region.

Keywords: Baltic Sea Region, convergence, modernization. 